\title{
OSCARKEMPFFITE, $\mathrm{Ag}_{10} \mathrm{~Pb}_{4}\left(\mathrm{Sb}_{17} \mathrm{Bi}_{9}\right)_{\Sigma 26} \mathrm{~S}_{48}$, A NEW Sb-Bi MEMBER OF THE LILLIANITE HOMOLOGOUS SERIES
}

\author{
Dan Topa ${ }^{1}$, Werner H. Paar ${ }^{2}$, Emil Makovicky ${ }^{3}$, Chris J. Stanley ${ }^{4}$ and Andy C. Roberts ${ }^{5}$ \\ ${ }^{1}$ Natural History Museum-Vienna, Burgring 7, A-1010 Vienna, Austria \\ ${ }^{2}$ A-5020 Salzburg, Pezoltgasse 46, Austria \\ ${ }^{3}$ Department of Geoscience and Resource Management, University of Copenhagen, \\ Østervoldgade 10, DK-1350,Copenhagen K, Denmark, \\ ${ }^{4}$ The Natural History Museum, Cromwell Road, London, SW7 5BD, England, UK \\ ${ }^{5}$ Geological Survey of Canada, 601 Booth Street, Ottawa, Ontario K1A OE8, Canada \\ *E-mail: dan.topa@sbg.ac.at
}

\begin{abstract}
Oscarkempffite, ideally $\mathrm{Ag}_{10} \mathrm{~Pb}_{4}\left(\mathrm{Sb}_{17} \mathrm{Bi}_{9}\right)_{\Sigma=26} \mathrm{~S}_{48}$, is a new mineral species found in old material (1929-30) from the Colorada vein, Animas mine, Chocaya Province, Department of Potosi, Bolivia. It is associated with aramayoite, stannite, miargyrite, pyrargyrite, and freibergite. Oscarkempffite forms anhedral grains, and grain aggregates up to $10 \mathrm{~mm}$ across. The mineral is opaque, greyish black with a metallic luster; it is brittle without any discernible cleavage. In reflected light oscarkempffite is grayish white, pleochroism is distinct, white to dark grey. Internal refleetions are absent. In crossed polars, anisotropism is distinct with rotation tints in shades of grey. The reflectance data (\%, air) are: $39.9,42.6$ at $470 \mathrm{~nm}, 38.6,41.7$ at $546 \mathrm{~nm}$, $38.1,41.2$ at $589 \mathrm{~nm}$ and $37.3,40.6$ at $650 \mathrm{~nm}$. Mohs hardness is $3-31 \frac{1}{2}$, microhardness $\mathrm{VHN}_{50}$ exhibits a range 189-208, with a mean value $200 \mathrm{~kg} \mathrm{~mm}^{-2}$. The average results of four electronmicroprobe analyses in a grain are: $\mathrm{Cu} 0.24(7), \mathrm{Ag} 14.50(8), \mathrm{Pb}$ 11.16(14), Sb 28.72(16), Bi 24.56(17), S 20.87(5), total 100.05(6) wt.\%, corresponding to $\mathrm{Cu}_{0.24} \mathrm{Ag}_{9.92} \mathrm{~Pb}_{4.00} \mathrm{Sb}_{17.36} \mathrm{Bi}_{8.64} \mathrm{~S}_{47.84}$ (on the basis of $M e+\mathrm{S}=88 \mathrm{apfu}$ ). The simplified formula, $\mathrm{Ag}_{10} \mathrm{~Pb}_{4} \mathrm{Sb}_{17} \mathrm{Bi}_{9} \mathrm{~S}_{48}$, is in accordance with the results of a crystal-structure determination. The density, $5.8 \mathrm{~g} / \mathrm{cm}^{3}$, was calculated using the ideal formula. Oscarkempffite has an orthorhombic cell with $a=13.199(2), b=19.332(3), c$ $=8.249(1) \AA, V=2116.3(5) \AA_{3}$, space group Pnca, and $Z=1$. The strongest eight lines in the (calculated) powder-diffraction pattern are $[d$ in $\AA(\mathrm{I}) h k l]: 3.66(35)(122), 3.37(70)(132)$, $3.34(100)(250), 2.982(55)(312), 2.881(86)(322), 2.733(29)(332), 2.073(27)(004)$ and 2.062(31)(182). Comparison with gustavite, andorite, and roshchinite confirms its independence as a mineral species.
\end{abstract}

Keywords: oscarkempffite, sulphosalt, new mineral, lillianite homologous series, Animas mine, Chocaya Province, Bolivia.

\section{INTRODUCTION}

The lillianite homologous series (Makovicky and Karup-Møller, 1977a, b) was defined for $\mathrm{Pb}-\mathrm{Bi}$-Ag sulfosalts although it was noticed already from the start that three antimony-based phases andorite, ramdohrite and fizelyite (Hellner, 1958) belonged to the same structural family. The andorite - ramdohrite branch of the lillianite series was subsequently studied in detail by Moëlo et al., (1989). Phases belonging to the lillianite homologous series are composed of slabs of the slightly distorted $\mathrm{PbS}$ archetypal structure, cut and mirror-twinned on (113) $\mathrm{Pbs}$. The octahedral coordinations present in the slabs are altered to bicapped prismatic coordinations on 
the composition plane between adjacent slabs. Slab thickness can vary by increments of one or more octahedra, measured diagonally across a slab. Number of octahedra along this diagonal determines the order $\mathrm{N}$ of the homologue. Substitution $[\mathrm{Ag}+(\mathrm{Sb}+\mathrm{Bi})]-$ for- $2 \mathrm{~Pb}$ is present in the slabs but in most cases it does not involve the prismatic lead positions. For $\mathrm{N}=4$, relevant for the present study, this substitution spans compositions from $\mathrm{Pb}_{3} \mathrm{Bi}_{2} \mathrm{~S}_{6}$ to $\mathrm{PbAg}(\mathrm{Bi}, \mathrm{Sb})_{3} \mathrm{~S}_{6}$, expressed as the substitution percentage from 0 to $100 \%$. The end-member composition $\mathrm{Pb}_{3} \mathrm{Sb}_{2} \mathrm{~S}_{6}$ is unknown, both as a natural and a synthetic phase, and probably cannot exist as a lillianite homologue. Cases of 'oversubstitution', in which also the prismatic position is involved, are known, mostly for the antimony-based cases (Moëlo et al., 1989). For $\mathrm{N}=4$, and a Bi-based case, an orthorhombic Bbmm structure exists for substitutions of up to about $60 \%$; whereas a monoclinic $P 2_{1} / c$ superstructure is present for substitutions close to $100 \%$ (Makovicky and Karup-Møller 1977b). The situation for the Sb-based phases is more complicated for the $\mathrm{N}=$ 4 line, with two highly substituted-to-oversubstituted phases (complicated 6-fold and 4-fold superstructures of the basic lillianite scheme) and several moderately substituted cases present, these often with other cations modifying the simple Pb-Ag-Sb scheme.

Studies of the mixed antimony-bismuth members of the lillianite homologous series were first limited to a chemical characterization of them by means of electron microprobe analyses. It was established (Mozgova et al., 1987, Moëlo et al., 1989) that extensive Bi-Sb substitution may be present, straddling the 50:50 Sb:Bi divide, although typical gustavites and lillianites have low contents of antimony (e.g., Makovicky and Topa, 2011, and the numerous references in Moëlo et al., 1989). In a similar way, nearly all occurrences of andorite-ramdohrite homologues have only low contents of bismuth (Moëlo et al., 1989). Notable occurrences of mixed Sb-Bi phases are Alyaskitovoye deposit (Yakutia, Russia) (Mozgova et al., 1987), Flat Head (Montana, USA) (Karup-Møller and Makovicky, unpublished), Julcani (Peru), El Mechero (Peru), Bazoges-enPaillers (Vendee, France) (all three by Moëlo et al., 1987), and Kutná Hora (Central Bohemia, Czech Republic) (Pažout et al., 2001). Investigations of mixed phases were mostly hampered by extreme variability of $\mathrm{Sb}: \mathrm{Bi}$ ratios, often inside one aggregate or a needle-shaped grain, typical for nearly all investigated occurrences. In spite of it, a successful crystal structure investigation was performed by Pažout and Dušek (2009) on antimony-containing gustavite, $\mathrm{PbAgBi}_{2} \mathrm{SbS}_{6}$, from the deposit of Kutná Hora, Czech Republic, with $a=7.0455 \AA, b=19.5294 \AA, c=8.3412$ $\AA$, and $\beta 107.446^{\circ}$, space group $P 2_{1} / c$. Another published structure of this category from Kutná Hora is that of $\mathrm{Ag}_{0.71} \mathrm{~Pb}_{1.52} \mathrm{Bi}_{1.32} \mathrm{Sb}_{1.45} \mathrm{~S}_{6}$, with $a=4.254 \AA, b=13.309 \AA, c=19.625 \AA$, space group Cmcm (Pažout and Dušek, 2010). This orthorhombic phase has substitution percentage of only $70.5 \%$, according to the substitution scheme defined above (Makovicky and Karup-Møller, 1977a, b and Makovicky and Topa 2014).

The new investigation of the old material from the Colorada vein, Animas mine, Chocaya Province, Department of Potosi, Bolivia (Ahlfeld and Reyes, 1938, Ahlfeld and SchneiderScherbina, 1964,) offered a chance to extend further the chemical range of investigated Sb-Bi lillianite homologues with $\mathrm{N}=4$ and led to the definition of oscarkempffite as a new species.

The mineral and its name have been approved by the CNMNC-IMA, under the number IMA-2011-029 (Topa et al., 2013). The name is in honor of Oscar Kempff Bacigalupo (1948- ), eminent Bolivian mineralogist and economic geologist, who discovered several large mineral deposits in Bolivia (e.g., the deposit of Don Mario). The holotype specimen of oscarkempffite is deposited in the reference collection of the Naturhistorisches Museum Wien, Burgring 7, A-1010 Wien, Austria, with catalogue number N 9593. Cotype material is deposited in the reference collection of the Natural History Museum, Cromwell Road, London SW7 5BD, United Kingdom, with catalogue number BM 20, 3.

\section{OCCURRENCE}


Oscarkempffite has been determined in old samples which originate from the expeditions of W. Vaux in 1929-30. The locality which is given on the labels associated with the two specimens of this mineral, is Animas mine, Colorada vein. Chocaya is a typical deposit of the $\mathrm{Ag}$-Sn formation of Bolivia. Its geographical position is $66^{\circ} 33^{\prime} \mathrm{W}$ and $21^{\circ} \mathrm{S}$. It is situated $\mathrm{NW}$ of Atocha in the province of Sur Chicas, department of Potosi, Southern Bolivia, and thus very close to the tectonic lineament which separates Paleozoic rocks of the Central Andes from the high planes (= altiplano) of Bolivia. The vein-type Ag-Sn deposits occur NE of a volcanic stock of dacitic rocks which has a diameter of $9 \mathrm{~km}$ and rises up against the Ordovician plane for more than 900 meters. The volcanic rocks are strongly altered and propylitization, silicification and pyritization are very common.

Colorada, which is the principal vein, follows a distinct fault zone for more than $1800 \mathrm{~m}$ along strike. Other veins which parallel the Colorada structure are Arturo and Animas towards $\mathrm{W}$, and Burton and Judíos towards E. The Colorada vein has been exploited towards depth for almost $750 \mathrm{~m}$ in the northern part and $600 \mathrm{~m}$ in the section of Animas in its southern part. In the upper part of this vein cassiterite was associated with freibergite and members of the stannitekësterite family. Textures which clearly indicated open space filling have very distinct banding, crustification and cockades.

At the Animas mine, some $70 \mathrm{~m}$ from the surface, an extremely rich ore shoot composed of various minerals of silver was encountered during the exploitation of the mine. At a depth of $125 \mathrm{~m}$, the ore shoot had a length of $30 \mathrm{~m}$, a thickness of $2 \mathrm{~m}$ and the grade of silver was almost $3.5 \%$. The principal silver mineral was freibergite. At the level $-235 \mathrm{~m}$ the high-grade zone contained the new mineral species aramayoite, $\mathrm{Ag}(\mathrm{Sb}, \mathrm{Bi})_{2}$, accompanied by stannite, miargyrite, pyrargyrite, and freibergite. Aramayoite has been described in detail by Spencer and Mountain (1926).

Oscarkempffite, the new sulfosalt species, is a typical associate of this assemblage containing aramayoite. Though no details about the exact level are given on the labels associated with the specimens, it can be assumed with certainty, that their origin is from the same level as the discovery of aramayoite $(-235 \mathrm{~m}$ level). The last and more important exploitation at the Animas mine stopped in 1961, when significant amounts of $\mathrm{Pb}, \mathrm{Ag}, \mathrm{Sn}$ and $\mathrm{Zn}$ were mined. However, small-scale mining by local mining communities ("cooperativas") at the deeper levels of the Animas mine was still going on at the time of the last visit of one of the authors (WHP, 2004) and probably continues to the present day.

\section{MINERAL ASSOCIATION}

Oscarkempffite forms anhedral grains attaining a size of up to several $\mathrm{mm}$ and grain aggregates ranging up to10 $\mathrm{mm}$ across. A BSE photograph (Fig. 1a) of such an aggregate shows differences in the contents of cations with high $Z$ values as smooth zoning with a higher average $\mathrm{Z}$ in the centre. The same aggregate in reflected light (Fig. 1b) displays an irregular mosaic character and pronounced anisotropy. Surrounding association is not visible because of high contrast. Figure 1c shows a large field of Ag-bearing tetrahedrite with another, silver richer (lighter on the BSE image) generation deposited in a void and irregular grains of oscarkempffite that penetrate into tetrahedrite on the boundary and enclose a small aramayoite grain. The complex round sulphide aggregate in Figure 1d is interpreted as a replacement of an old unknown precursor mineral (aggregate) of approximately round shape by oscarkempffite (a 'wreath' of light grains and a grain in the centre) cemented by a large grain of bismuth-rich aramayoite (lighter grey) and another of less bismuthian aramayoite variety (slightly darker grey, lower left-hand parts). Small crystals of quartz and a grain of tetrahedrite with a 'cap' of Agenriched tetrahedrite variety (dark grey on the BSE image) are enclosed. Close to the lower corners of the figure, dark semi-decomposed grains of stannite are present. Oscarkempffite overgrew/replaced the original aggregate from the outside and later also the remaining old grain. 
Much of oscarkempffite was subsequently replaced by aramayoite. Stannite apparently predates aramayoite, as seen in the lower right-hand corner.

\section{PHYSICAL PROPERTIES}

The colour of the mineral is greyish black, streak dark grey; it is opaque with metallic luster, non-fluorescent. $\mathrm{H}(\mathrm{Mohs})$ is $3-3 \frac{1}{2}$, microhardness $\mathrm{VHN}_{50}$ is ranging between 189 and 208, with a mean value $200 \mathrm{~kg} \mathrm{~mm}^{-2}$. The mineral is brittle with irregular fracture; no cleavage or parting are observed. Density could not be measured because of paucity of available material. Calculated density is $5.8 \mathrm{~g} \mathrm{~cm}^{-3}$ using the empirical formula. No crystal forms and twinning of the anhedral grains and aggregates were observed. The $a: b: c$ ratio calculated from the unit-cell parameters (see below) is 0.683:1:0.429.

\section{OPTICAL PROPERTIES}

In reflected light (plane polars) the colour of oscarkempffite is grayish white. Pleochroism is distinct, white to dark grey; bireflectance is weak to distinct (in oil); no internal reflections were detected. With crossed polars, anisotropism is distinct with rotation tints in shades of grey. Reflectance values in air and oil, (The Natural History Museum, London, UK, WTiC standard, refractive index of oil: 1.515 at $23^{\circ} \mathrm{C}$ ) are given in Table 1. A slight, fairly even decrease of reflectance with increasing wavelength is observed.

\section{CHEMICAL DATA}

Chemical analyses of oscarkempffite (Table 2) were carried out using an electron microprobe JEOL JXA-8600, installed at University of Salzburg, Austria, (WDS mode, $25 \mathrm{kV}$, $20 \mathrm{nA}, 5 \mu \mathrm{m}$ beam diameter, ZAF correction procedure). Other elements ( $\mathrm{Hg}, \mathrm{Tl}$ and $\mathrm{As})$ were sought but not detected. The standards and wavelengths used are chalcopyrite (nat.) $\mathrm{CuK \alpha}$, $\mathrm{Fe} K \alpha$, shalerite (nat.) $\mathrm{Zn} K \alpha$, metal (syn.) $\mathrm{Ag} L \alpha$, galena (nat.) $\mathrm{Pb} L \alpha$, stibnite (nat.) $\mathrm{Sb} L \alpha$ and bismuthinite (syn.) $\mathrm{Bi} L \alpha$ and $\mathrm{S} K \alpha$. Data for oscarkempffite and associated minerals are presented in Table 2 .

The empirical formula of oscarkempffite varies between $(\mathrm{Ag}, \mathrm{Cu})_{9.88} \mathrm{~Pb}_{4.40} \mathrm{Sb}_{18.0} \mathrm{Bi}_{7.44} \mathrm{~S}_{48.32}$ and $(\mathrm{Ag}, \mathrm{Cu})_{10.24} \mathrm{~Pb}_{3.68} \mathrm{Sb}_{16.40} \mathrm{Bi}_{9.44} \mathrm{~S}_{48.32}$. It is very close to the simplified formula $\mathrm{Ag}_{10} \mathrm{~Pb}_{4}\left(\mathrm{Sb}_{17} \mathrm{Bi}_{9}\right)_{26} \mathrm{~S}_{48}$. The crystal structure defines oscarkempffite as a lillianite homologue with the order $\mathrm{N}=4$. The cation ratios resulting from the chemical analysis confirm this assignment, yielding $\mathrm{N}=4.07-4.09$. With respect to the measure of $[\mathrm{Ag}+(\mathrm{Bi}, \mathrm{Sb})] \leftrightarrow 2 \mathrm{~Pb}$ substitution, typical for the lillianite-gustavite and fizelyite-andorite substitution lines (both $\mathrm{N}=$ 4), oscarkempffite is heavily over-substituted, with a substitution percentage of $120-124 \%$.

Chemical analyses (Table 2) of aggregates shown in Figure 1d represent three groups of oscarkempffite chemistries and two types of tetrahedrite illustrated, among which the one richest in $\mathrm{Ag}$ represents the minor later phase (Fig. 1c). Among the three analyses of aramayoite, nos. 3 and 4 represent the aggregate in Figure 1d, no. 5 another aggregate. In conclusion, they show a substantial variability of the $\mathrm{Sb} / \mathrm{Bi}$ ratio.

\section{CRYSTALLOGRAPHY}

A diffractometer with an area detector system was used to perform the single-crystal study (University of Salzburg, Austria). Cell parameters refined from single-crystal data are as follows: orthorhombic system, space group Pnca, $a=13.199(2) \AA, b=19.332(3) \AA, c=8.294(1) \AA$, cell volume $V=2116.3(5) \AA^{3}$, and $Z=1$ for the above formula unit. 
Powder X-ray data were collected using a $114.6 \mathrm{~mm}$ diameter Debye-Scherrer camera (Cu radiation, Ni filter, $\mathrm{Cu} K \alpha=1.54178 \AA$ ). Data are presented in Table 3. The calculated powder data from results of the single-crystal study are shown in Table 4. Cell parameters refined from the powder data are as follows: $a=13.240(5) \AA, b=19.339(7) \AA, c=8.320(4) \AA$, and $V=2130(2) \AA^{3}$, in fair agreement with the single-crystal data.

\section{CRYSTAL STRUCTURE}

A fragment with irregular shape and $0.15 \times 0.05 \times 0.05 \mathrm{~mm}$ in size was mounted and analyzed on a Bruker AXS three-circle diffractometer equipped with a CCD area detector. The structure of oscarkempffite contains five distinct coordination polyhedra of cations and seven of anions. It contains a mixed $(\mathrm{Pb}, \mathrm{Bi})$ site with a trigonal prismatic coordination, a silver site with a distorted tetrahedral coordination in an octahedral arrangement of ligands, which alternates along the $8 \AA$ direction with a mixed $\left(\mathrm{Sb}_{0.88} \mathrm{Bi}_{0.12}\right)$ site called $\mathrm{Sb} 1$, and a string of alternating $\mathrm{Sb} 2$ and a mixed $\left(\mathrm{Sb}_{0.59} \mathrm{Bi}_{0.41}\right)$ sites, the latter called $\mathrm{Sb} 3$, in the central parts of $\mathrm{PbS}-$ like slabs. When proceeding along [100], the arrangement of consecutive atomic planes differs from that in the monoclinic gustavite structure, resulting in orthorhombic symmetry and in -Sb$\mathrm{Sb}-\mathrm{Ag}-\mathrm{Ag}-\mathrm{Sb}-\mathrm{Sb}$ - zig-zag [010] chains of coordination octahedra instead of the Ag-Bi-Ag-Bichains present in gustavite. The crystal structure is shown in Figure 2.

Details of the crystal structure and the interesting geometric relationships between the structures of orthorhombic oscarkempffite and monoclinic gustavite $\mathrm{PbAgBi}_{3} \mathrm{~S}_{6}$ are treated in a parallel paper (Topa and Makovicky, submitted).

\section{RELATION TO OTHER SPECIES}

Oscarkempffite is essentially a pure $\mathrm{Ag}-(\mathrm{Sb}, \mathrm{Bi})-\mathrm{Pb}$ sulfosalt with only trace amounts of copper and without As. It is a lillianite homologue $\mathrm{N}=4$ as confirmed by the $\mathrm{N}$ value calculated from the chemical analysis. With respect to the measure of $(\mathrm{Ag}+\mathrm{Bi}) \leftrightarrow 2 \mathrm{~Pb}$ substitution, typical of the lillianite-gustavite and fizelyite-andorite substitution lines, oscarkempffite is heavily oversubstituted, with a substitution percentage of $124 \%$, far beyond the $100 \%$ value of gustavite, $\mathrm{PbAgBi}_{3} \mathrm{~S}_{6}$ (Makovicky and Karup-Møller, 1977a,b) and the $\sim 100 \%$ value of senandorite (andorite VI; Sawada et al., 1987). In this, it resembles the partly heterogeneous 'bismuthian andorites' from Julcani, Peru, analysed by Moëlo et al., (1989) without crystallographic studies. They are distinguished by higher contents of copper, constant presence of arsenic (mostly between 1.2 and 2.5 wt. \%), substitution percentages between $\sim 101$ and $119 \%$ and very variable $\mathrm{Sb}:$ Bi ratios (Moëlo et al., 1989).

The orthorhombic Sb-Bi member of the lillianite homologous series from Kutná Hora (Czech Republic), investigated by Pažout and Dušek (2010) has the composition $\mathrm{Ag}_{0.71} \mathrm{~Pb}_{1.52} \mathrm{Bi}_{1.32} \mathrm{Sb}_{1.45} \mathrm{~S}_{6}$. It has substitution percentage of only $70.5 \%$ and its lattice, with $a=$ $4.254 \AA, b=13.309 \AA, c=19.625 \AA$, space group $\mathrm{Cmcm}$, corresponds to a classical unit cell of lillianite. Oscarkempffite also resembles roshchinite (Spiridonov et al., 1990) from Kvartsitovye Gorki deposit, Kazakhstan, for which published data indicate a substitution value of $120 \%$. In roshchinite, however, $\mathrm{Bi}$ is absent, As is present in $3.5 \mathrm{wt} . \%$, and the crystal structure has not been worked out beyond the subcell of andorite type (Petrova et al., 1986). Comparative data for oscarkempffite and related minerals are given in Table 5.

\section{ACKNOWLEDGEMENTS}


We appreciate very much the information about the geology at Chocaya communicated by Dr. Sohrab Tawackoli, La Paz. The two specimens containing the new species were provided by Dr. Rob Lavinsky (Arkenstone). They were originally part of the famous Philadelphia collection which contained a lot of historically important materials. The paper was handled by......and the comments of Dr. Nigel Cook and an anonymous referee helped to improve the paper.

\section{REFERENCES}

Ahlfeld, F. and Reyes, J.M. (1938) Mineralogie von Bolivien. Berlin, Verlag: Gebrüder Borntraeger, 90p.

Ahlfeld, F. and Schneider-Scherbina, A. (1964) Los yacimientos minerales y de hidrocarburos de Bolivia. Boletín de Departamento Nacional de Geología del Ministerio de Minas y Petroléo, $\mathbf{5}$, (Especial), La Paz, 388 p.

Hellner, E. (1958) A structural scheme for sulfide minerals. J.Geol. 66, 503-525.

Kraus, W. and Nolze, G. (1999) PowderCell 2.3. Federal Institute for Materials Research and Testing, Berlin, Germany.

Makovicky, E. and Karup-Møller, S. (1977a) Chemistry and crystallography of the lillianite homologous series. Part 1. General properties and definitions. Neues Jahrbuch für Mineralogie, Abhandlugen, 130, 264-287.

Makovicky, E. and Karup-Møller, S. (1977b) Chemistry and crystallography of the lillianite homologous series. Part 2. Definition of new minerals: eskimoite, vikingite, ourayite and treasurite. Redefinition of schirmerite and new data on the lillianite-gustavite solid-solution series. Neues Jahrbuch für Mineralogie, Abhandlugen, 131, 56-82.

Makovicky, E. and Topa D. (2011) The crystal structure of gustavite, $\mathrm{PbAgBi}_{3} \mathrm{~S}_{6}$. Analysis of twinning and polytypism using the OD approach. European Journal of Mineralogy 23, 537-550.

Makovicky, E. and Topa D. (2014) Lillianites and andorites: new life for the oldest homologous series of sulphosalts. Mineralogical Magazine, 78, 387-414.

Moëlo, Y., Makovicky, E. and Karup-Møller, S. (1989) Sulfures complexes plombo argentifères : minéralogie et cristallochimie de la série andorite-fizélyite, $(\mathrm{Pb}, \mathrm{Mn}, \mathrm{Fe}, \mathrm{Cd}, \mathrm{Sn})_{3-2 x}(\mathrm{Ag}, \mathrm{Cu})_{x}(\mathrm{Sb}, \mathrm{Bi}, \mathrm{As})_{2+x}(\mathrm{~S}, \mathrm{Se})_{6}$. Documents du BRGM, 167, 1-107.

Pažout, R. and Dušek, M. (2009) Natural monoclinic $\mathrm{AgPb}\left(\mathrm{Bi}_{2} \mathrm{Sb}\right)_{3} \mathrm{~S}_{6}$, an Sb-rich gustavite. Acta Crystallographica, C65(11), 177-180.

Pažout, R. and Dušek, M. (2010) Crystal structure of natural orthorhombic $\mathrm{Ag}_{0.71} \mathrm{~Pb}_{1.52} \mathrm{Bi}_{1.32} \mathrm{Sb}_{1.45} \mathrm{~S}_{6}$, a lillianite homologue with $\mathrm{N}=4$; comparison with gustavite. European Journal of Mineralogy 22, 741-750.

Petrova, I.V., Pobedimskaya, E.A. and Spiridonov, E.M. (1986) Crystal structure of roshchinite. Materialy X. Vsesoyuz. Sov. po Rentgenografii Mineral'nogo Syrya, Tbilisi, 99-100 (in Russian). 
Sawada, H., Kawada, I., Hellner, E. and Tokonami, M. (1987) The crystal structure of senandorite (andorite VI): $\mathrm{PbAgSb}{ }_{3} \mathrm{~S}_{6}$. Zeitschrift für Kristallographie 180, 141-150.

Spencer, L.J. and Mountain, E.D. (1926) Aramayoite, a new mineral from Bolivia. Mineralogical Magazine, 21, 156-162.

Spiridonov, E.M., Petrova, I.V., Dashevskaya, D.M., Balashov, E.P. and Klimova, L.M. (1990) Roshchinite, $\mathrm{Pb}_{10} \mathrm{Ag}_{19} \mathrm{Sb}_{51} \mathrm{~S}_{96}$ - a new mineral. Doklady Akademii Nauk SSSR, 312, 197-200.

Topa, D., Makovicky, E., Paar, W.H., Stanley, C.J. and Roberts, A.C. (2011) Oscarkempffite, IMA 2011-029. CNMNC Newsletter No. 10, October 2011, page 2607; Mineralogical Magazine, 75, 2601-2613.

\section{FIGURE CAPTIONS}

Fig. 1. (a) A BSE photograph of an aggregate of oscarkempffite shows differences in the contents of cations with high $\mathrm{Z}$ values as smooth zoning with a higher average $\mathrm{Z}$ in the centre. (b) The same aggregate in reflected light displays an irregular mosaic character and pronounced anisotropy. Associated with pyrite. (c) A large field of Ag-bearing tetrahedrite with another, still silver richer (lighter) generation deposited in a void. Irregular grains of oscarkempffite penetrate into tetrahedrite on the boundary and enclose a small aramayoite grain. (d) A complex round sulfide aggregate interpreted as a replacement of an old unknown mineral aggregate.

Oscarkempffite (a 'wreath' of light grains and a grain in the centre) is corroded and cemented by a later, large grain of Bi-rich aramayoite (lighter grey) and another grain of Bi-poorer aramayoite (slightly darker grey, left-hand parts). Small crystals of quartz and a grain of tetrahedrite with a 'cap' of Ag-enriched tetrahedrite (dark grey) are enclosed. At lower corners of the figure, dark semi-decomposed grains of stannite are present. Interpretation in the text.

Fig. 2. Cation and anion sites in the crystal structure of oscarkempffite. Unit cell is projected on (001). In the order of decreasing size spheres indicate: $\mathrm{S},(\mathrm{Pb}, \mathrm{Bi})$ (grey), ( $\mathrm{Sb}, \mathrm{Bi}$ ) (white) and Ag (black). The (311) Pbs slabs of PbS-like arrangement are perpendicular to [010]; they are separated by $(010)$ planes occupied by trigonal coordination prisms of $(\mathrm{Pb}, \mathrm{Bi})$. 
Table 1. Reflectance values in air and oil (WTiC standard, refractive index of oil: 1.515 at $23^{\circ} \mathrm{C}$ ) for oscarkempffite.

\begin{tabular}{cccccccccc}
\hline \multicolumn{3}{c}{ air } & \multicolumn{9}{c}{ oil } & \multicolumn{2}{c}{ air } & \multicolumn{2}{c}{ oil } \\
$\lambda(\mathrm{nm})$ & $R_{\min }$ & $R_{\max }$ & $R_{\min }$ & $R_{\max }$ & $\lambda(\mathrm{nm})$ & $R_{\min }$ & $R_{\max }$ & $R_{\min }$ & $R_{\max }$ \\
\hline 400 & 41.6 & 44.4 & 26.0 & 41.6 & 560 & 38.4 & 41.5 & 22.4 & 38.4 \\
420 & 40.8 & 43.6 & 25.4 & 40.8 & 580 & 38.1 & 41.3 & 22.2 & 38.1 \\
440 & 40.5 & 43.2 & 24.7 & 40.5 & $\mathbf{5 8 9}$ & $\mathbf{3 8 . 1}$ & $\mathbf{4 1 . 2}$ & $\mathbf{2 2 . 1}$ & $\mathbf{3 8 . 1}$ \\
460 & 40.1 & 42.7 & 24.3 & 40.1 & 600 & 38.0 & 41.1 & 22.0 & 38.0 \\
$\mathbf{4 7 0}$ & $\mathbf{3 9 . 9}$ & $\mathbf{4 2 . 6}$ & $\mathbf{2 4 . 1}$ & $\mathbf{3 9 . 9}$ & 620 & 37.7 & 40.8 & 21.7 & 37.7 \\
480 & 39.7 & 42.5 & 23.8 & 39.7 & 640 & 37.4 & 40.7 & 21.7 & 37.4 \\
500 & 39.4 & 42.2 & 23.5 & 39.4 & $\mathbf{6 5 0}$ & $\mathbf{3 7 . 3}$ & $\mathbf{4 0 . 6}$ & $\mathbf{2 1 . 4}$ & $\mathbf{3 7 . 3}$ \\
520 & 39.0 & 42.0 & 23.1 & 39.0 & 660 & 37.1 & 40.4 & 21.3 & 37.1 \\
540 & 38.7 & 41.7 & 22.7 & 38.7 & 680 & 36.9 & 40.2 & 21.1 & 36.9 \\
$\mathbf{5 4 6}$ & $\mathbf{3 8 . 6}$ & $\mathbf{4 1 . 7}$ & $\mathbf{2 2 . 6}$ & $\mathbf{3 8 . 6}$ & 700 & 36.8 & 39.9 & 21.1 & 36.8 \\
\hline
\end{tabular}


Table 2. Analytical results for oscarkempffite and associated minerals.

\begin{tabular}{cccccccccccc}
\hline $\mathrm{Nr}$. & Mineral & $\mathrm{NA}$ & $\mathrm{Cu}$ & $\mathrm{Ag}$ & $\mathrm{Fe}$ & $\mathrm{Zn}$ & $\mathrm{Pb}$ & $\mathrm{Sb}$ & $\mathrm{Bi}$ & $\mathrm{S}$ & total \\
\hline 1 & tetrahedrite & 16 & $23.99(30)$ & $19.97(20)$ & $5.64(12))$ & $0.87(13))$ & - & $26.39(39)$ & - & $23.00(14)$ & $99.86(30)$ \\
2 & tetrahedrite & 3 & $17.38(24)$ & $28.63(01)$ & $4.98(31)$ & $1.34(19)$ & - & $25.55(06)$ & - & $22.18(12)$ & $100.06(04)$ \\
3 & aramayoite & 3 & - & $34.26(23)$ & - & - & - & $27.70(33)$ & $17.50(44)$ & $20.06(09)$ & $99.52(21)$ \\
4 & aramayoite & 3 & - & $35.26(28)$ & - & - & - & $30.55(19)$ & $13.48(25)$ & $20.53(03)$ & $99.82(11)$ \\
5 & aramayoite & 3 & - & $36.34(12)$ & - & - & - & $36.83(68)$ & $5.45(56)$ & $21.05(07)$ & $99.67(11)$ \\
6 & oscarkempffite & 5 & $0.35(07)$ & $13.98(19)$ & - & - & $12.56(77)$ & $30.13(49)$ & $21.41(20)$ & $21.33(12)$ & $99.76(13)$ \\
7 & oscarkempffite & 4 & $0.24(03)$ & $14.50(08)$ & & & $11.16(14)$ & $28.72(16)$ & $24.56(17)$ & $20.87(05)$ & $100.05(06)$ \\
8 & oscarkempffite & 4 & $0.29(04)$ & $14.48(08)$ & - & - & $10.03(36)$ & $27.12(40)$ & $26.73(37)$ & $21.04(15)$ & $99.96(32)$ \\
\hline
\end{tabular}

The data are expressed in wt.\%. NA $=$ Number of analyses. Formulae are calculated on the basis of $\Sigma(M e+\mathrm{S})=29$ a.p.f.u. for tetrahedrite, 24 a.p.f.u. for aramayoite, and 88 a.p.f.u. for oscarkempffite, respectively. $\mathrm{N}_{\text {chemical }}$ and $\mathrm{Ag}_{\text {subst }}$ are calculated as described in Makovicky and Topa (2014).

1: $\mathrm{Cu}_{6.80} \mathrm{Ag}_{3.33} \mathrm{Fe}_{1.82} \mathrm{Zn}_{0.24} \mathrm{Sb}_{3.90} \mathrm{~S}_{12.91}$

2: $\mathrm{Cu}_{5.12} \mathrm{Ag}_{4.97} \mathrm{Fe}_{1.67} \mathrm{Zn}_{0.38} \mathrm{Sb}_{3.93} \mathrm{~S}_{12.94}$

3: $\mathrm{Ag}_{6.08} \mathrm{Sb}_{4.35} \mathrm{Bi}_{1.60} \mathrm{~S}_{11.97}$

4: $\mathrm{Ag}_{6.12} \mathrm{Sb}_{4.70} \mathrm{Bi}_{1.21} \mathrm{~S}_{11.98}$

5: $\mathrm{Ag}_{6.12} \mathrm{Sb}_{5.49} \mathrm{Bi}_{0.47} \mathrm{~S}_{11.92}$

6: $\mathrm{Cu}_{0.40} \mathrm{Ag}_{9.44} \mathrm{~Pb}_{4.40} \mathrm{Sb}_{18.00} \mathrm{Bi}_{7.44} \mathrm{~S}_{48.32} ; \mathrm{N}_{\text {chemical }}=4.08, \mathrm{Ag}_{\text {subst }}=121 \%$

7: $\mathrm{Cu}_{0.24} \mathrm{Ag}_{9.92} \mathrm{~Pb}_{4.00} \mathrm{Sb}_{17.36} \mathrm{Bi}_{8.64} \mathrm{~S}_{47.84} ; \mathrm{N}_{\text {chemical }}=4.07, \mathrm{Ag}_{\text {subst }}=124 \%$

8: $\mathrm{Cu}_{0.32} \mathrm{Ag}_{9.92} \mathrm{~Pb}_{3.68} \mathrm{Sb}_{16.40} \mathrm{Bi}_{9.44} \mathrm{~S}_{48.32} ; \mathrm{N}_{\text {chemical }}=4.09, \mathrm{Ag}_{\text {subst }}=125 \%$ 
Table 3. X-ray powder diffraction data for oscarkempffite.

\begin{tabular}{cccccc}
\hline$I_{\text {rel. }}$ & $d_{\text {meas }} / \AA$ & $d_{\text {cald }} \AA$ & $h$ & $k$ & $l$ \\
\hline 5 & 6.292 & 6.263 & 2 & 1 & 0 \\
5 & 5.463 & 5.463 & 2 & 2 & 0 \\
$20^{*}$ & 3.904 & 3.904 & 2 & 4 & 0 \\
$30^{*}$ & 3.663 & 3.672 & 1 & 2 & 2 \\
& & 3.380 & 1 & 3 & 2 \\
$100 \mathrm{~b}$ & 3.354 & 3.340 & 2 & 5 & 0 \\
$20^{*}$ & 3.264 & 3.263 & 4 & 1 & 0 \\
5 & 3.053 & 3.068 & 1 & 4 & 2 \\
$40^{*}$ & 2.988 & 2.991 & 3 & 1 & 2 \\
$80^{*}$ & 2.889 & 2.889 & 3 & 2 & 2 \\
$30^{*}$ & 2.741 & 2.740 & 3 & 3 & 2 \\
$10^{*}$ & 2.551 & 2.550 & 2 & 7 & 0 \\
$5 *$ & 2.417 & 2.417 & 0 & 8 & 0 \\
$40^{*}$ & 2.263 & 2.267 & 1 & 7 & 2 \\
$20^{*}$ & 2.112 & 2.111 & 5 & 3 & 2 \\
& & 2.073 & 0 & 0 & 4 \\
60 & 2.066 & 2.062 & 1 & 8 & 2 \\
$30^{*}$ & 2.027 & 2.028 & 5 & 4 & 2 \\
$30^{*}$ & 2.008 & 2.008 & 6 & 4 & 0 \\
& & 1.933 & 0 & 10 & 0 \\
30 & 1.931 & 1.930 & 5 & 5 & 2 \\
$20 *$ & 1.890 & 1.889 & 3 & 8 & 2 \\
$10^{*}$ & 1.834 & 1.836 & 5 & 6 & 2 \\
$5^{*}$ & 1.803 & 1.802 & 4 & 9 & 0 \\
$50^{*} \mathrm{~b}$ & 1.766 & 1.766 & 2 & 5 & 4 \\
$10^{*}$ & 1.722 & 1.722 & 7 & 0 & 2 \\
\hline & & & & &
\end{tabular}

*Lines used for unit cell refinement. Indexed on $a$ 13.240(5), $b$ 19.339(7), $c$ 8.320(4) $\AA$; refined on 17 reflections, between 3.904 and $1.772 \mathrm{~A}$, for which unambiguous indexing was possible, based on the calculated powder pattern derived from the successful determination of the crystal structure; intensities were estimated visually; $b=$ broad line; the pattern was not corrected for shrinkage and no internal standard was used. 
Table 4. Calculated X-ray powder diffraction data for oscarkempffite.*

\begin{tabular}{|c|c|c|c|c|c|c|c|c|}
\hline$I_{\text {rel. }}$ & $d_{\text {cald }} / \AA$ & $h$ & $k \quad l$ & $I_{\text {rel. }}$ & $d_{\text {cald }} / \AA$ & $h$ & $k$ & $l$ \\
\hline 8 & 6.25 & 2 & 10 & 31 & 2.062 & 1 & 8 & 2 \\
\hline 10 & 5.45 & 22 & 20 & 29 & 2.023 & 5 & 4 & 2 \\
\hline 20 & 3.90 & 2 & 40 & 16 & 2.002 & 6 & 4 & 0 \\
\hline 35 & 3.66 & 12 & 22 & 9 & 1.9332 & 0 & 10 & 0 \\
\hline 70 & 3.37 & 13 & 32 & 9 & 1.9297 & 5 & 5 & 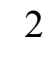 \\
\hline 100 & 3.34 & 2 & 50 & 14 & 1.8863 & 3 & 8 & 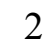 \\
\hline 15 & 3.30 & 4 & 00 & 8 & 1.8319 & 5 & 6 & . \\
\hline 22 & 3.25 & 4 & 10 & 5 & 1.8002 & 4 & 9 & 0 \\
\hline 6 & 3.22 & 0 & 60 & 24 & 1.7610 & 2 & 5 & 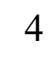 \\
\hline 55 & 2.982 & 3 & 12 & 5 & 1.7556 & 4 & 0 & 4 \\
\hline 25 & 2.895 & 2 & 60 & 5 & 1.7500 & 3 & 9 & 2 \\
\hline 86 & 2.881 & 32 & 22 & 5 & 1.7484 & 4 & 1 & 4 \\
\hline 29 & 2.733 & 3 & 32 & 6 & 1.7165 & 7 & 0 & 2 \\
\hline 5 & 2.548 & 2 & 70 & 6 & 1.6858 & 2 & 6 & . \\
\hline 21 & 2.265 & 1 & 72 & 6 & 1.6680 & 4 & 10 & 0 \\
\hline 13 & 2.105 & $5 ?$ & 32 & 6 & 1.6264 & 8 & 2 & 0 \\
\hline 5 & 2.082 & $6 ?$ & 30 & 7 & 1.4403 & 6 & 4 & 4 \\
\hline 27 & 2.073 & 0 & $\begin{array}{ll}04 \\
\end{array}$ & 5 & 1.4140 & 0 & 10 & \\
\hline
\end{tabular}

*The theoretical pattern was calculated with PowderCell 2.3 software (Kraus and Nolze, $1999)$ in Debye-Scherrer configuration employing $\mathrm{CuK \alpha}$ radiation $(\lambda=1.540598 \AA)$, a fixed slit, and no anomalous dispersion. Cell parameters, space group, atom positions, siteoccupancy factors and isotropic displacement factors from the crystal-structure determination were used. 
Table 5. Comparative data for oscarkempffite and related minerals.

\begin{tabular}{ccccc}
\hline Mineral & oscarkempffite & gustavite $^{1}$ & ${\text { andorite } \mathrm{VI}^{2}}^{2}$ & roshchinite $^{3}$ \\
\hline Formula & $\mathrm{Ag}_{10} \mathrm{~Pb}_{4} \mathrm{Sb}_{17} \mathrm{Bi}_{9} \mathrm{~S}_{48}$ & $\mathrm{Ag}_{4} \mathrm{~Pb}_{4} \mathrm{Bi}_{9} \mathrm{Sb}_{3} \mathrm{~S}_{24}$ & $\mathrm{Ag}_{6} \mathrm{~Pb}_{6} \mathrm{Sb}_{18} \mathrm{~S}_{36}$ & $\mathrm{Ag}_{9.5} \mathrm{~Pb}_{5} \mathrm{Sb}_{25.5} \mathrm{~S}_{48}$ \\
Substitution (\%) & 124 & 100 & 100 & 120 \\
Crystal system & orthorhombic & monoclinic & orthorhombic & orthorhombic \\
Space group & $P n c a$ & $P 2_{1} / c$ & $P n 2_{1} a$ & Pmna \\
Cell parameters $(\AA)$ & & & & \\
$a$ & 13.199 & 7.046 & 13.005 & 12.946 \\
$b$ & 19.332 & 19.529 & 19.155 & 19.048 \\
$c$ & 8.294 & 8.342 & 25.622 & 16.932 \\
$\alpha, \beta, \gamma\left(^{\circ}\right)$ & $90,90,90$ & $90,107.45,90$ & $90,90,90$ & $90,90,90$ \\
$Z$ & 1 & 1 & 1 & 2 \\
$R_{1}$ factor $(\%)$ & 3.7 & 5.88 & 4.89 & - \\
$\operatorname{Ref}^{4}$. & 1 & 2 & 3 & 4,5 \\
\hline
\end{tabular}

${ }^{1}$ Also gustavite with less $\mathrm{Sb}$ substitution, $\mathrm{Ag}_{4} \mathrm{~Pb}_{4} \mathrm{Bi}_{11.2} \mathrm{Sb}_{0.8} \mathrm{~S}_{24}$, with $a=7.056, b=9.691, c=$ $8.222 \AA, \beta=106.9^{\circ}$, space group $P 2{ }_{1} / c, R_{1}=2.76 \%$, by Makovicky and Topa (2011). ${ }^{2}$ Or senandorite. ${ }^{3}$ Tentative crystal structure refinement of Petrova et al. (1986). ${ }^{4}$ [1]: this study; [2]: Pažout \& Dušek (2010); [3]: Sawada et al. (1987); [4]: Spiridonov et al. (1990); [5]: Petrova et al. (1986). 

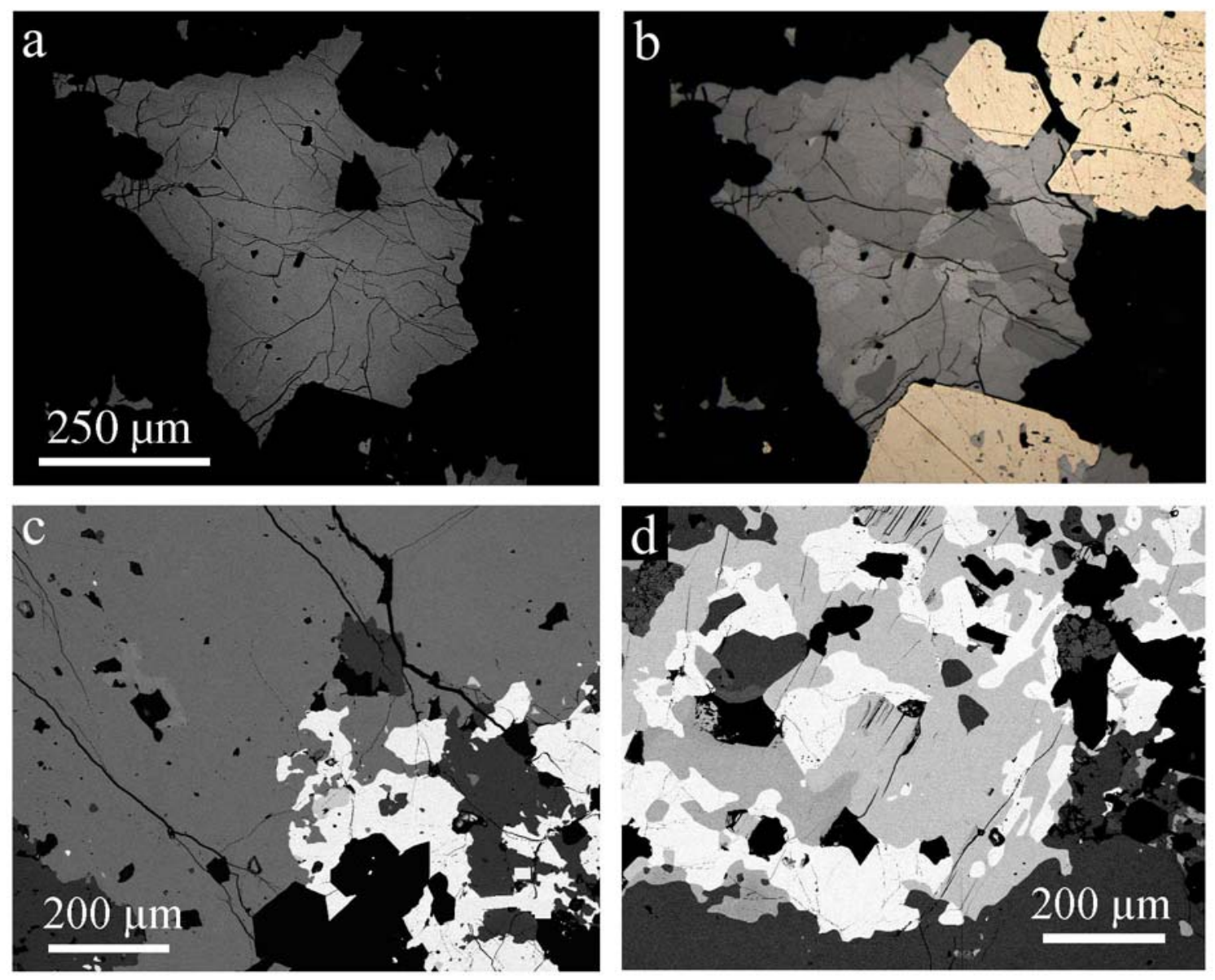

This is a 'preproof' accepted article for Mineralogical Magazine. 


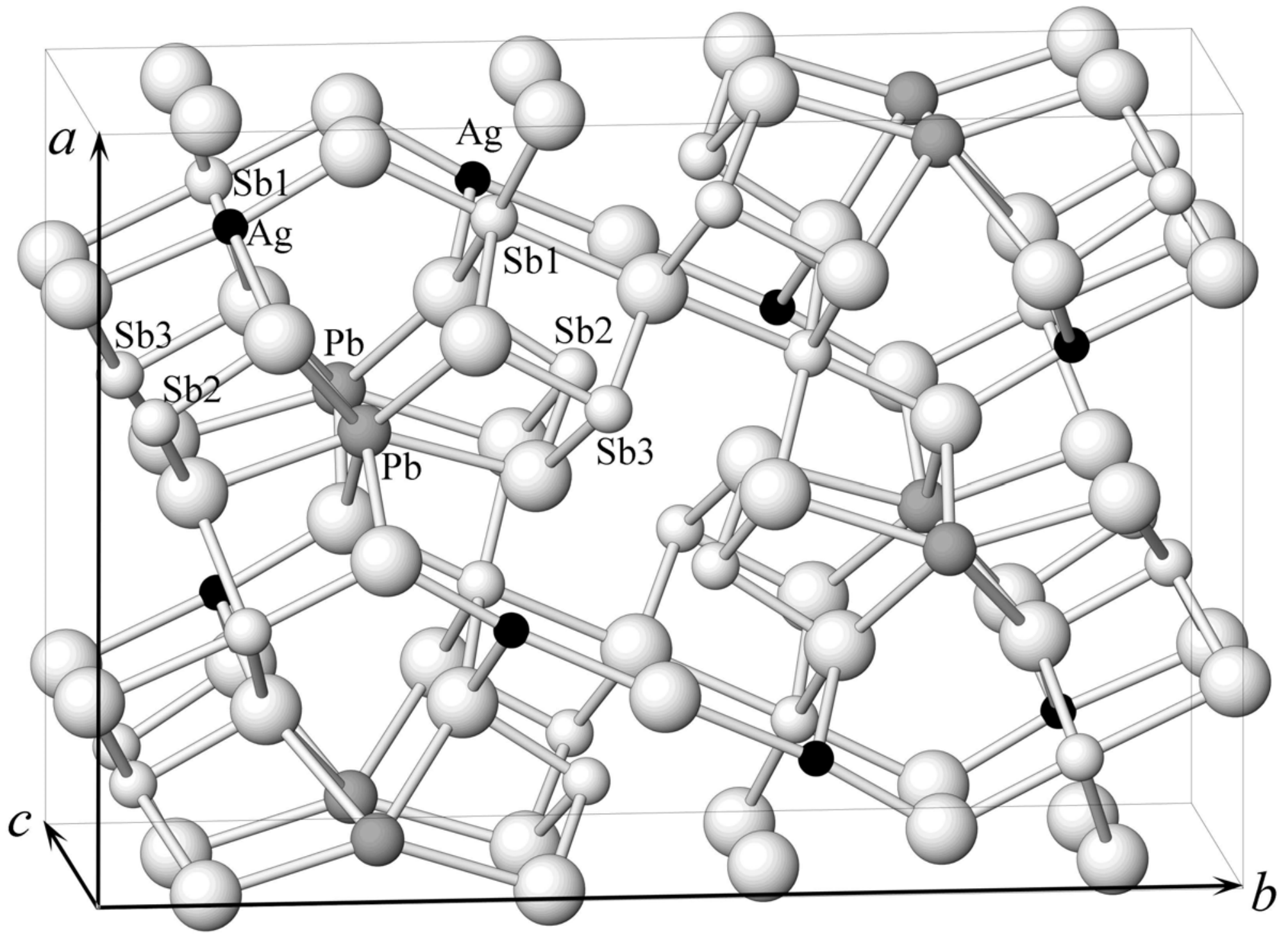

This is a 'preproof' accepted article for Mineralogical Magazine. 